\title{
Personal Data Protection and Access to Archives in Ukraine: From the National and International Perspective
}

\section{MARYNA PALIIENKO, DR.}

Professor, Doctor of Science (History), Head of Department of Archival Studies and Special Historical Disciplines, Taras Shevchenko National University of Kyiv, Ukraine

e-mail: mpaliienko@gmail.com

Personal Data Protection and Access to Archives in Ukraine: From the National and International Perspective

\section{ABSTRACT}

The article is devoted to the analysis of the General Data Protection Regulation, which came into force on May 25, 2018 , on the territory of the member states of the European Union, in comparison with the legislation on personal data that operates in Ukraine. The following basic concepts such as "personal data", "personal data bases", "information protection", "the right to access to information", "the right to erasure" are considered. Special attention is paid to the activities of archives in collecting, processing, storing and providing access to documents that contain personal information. It is analyzed the Laws of Ukraine "On Information", "On Protection of Personal Data", "On Access to Public Information", "On the National Archival Fond and Archival Institutions". It has been pointed out that the GDPR has very important value for European socio-political and economic life, for working out data protection standards and a new international privacy protection framework.

Key words: personal data protection, General Data Protection Regulation, Ukraine, archival law, access to information

Protezione dei dati personali e accesso agli archivi in Ucraina da una prospettiva nazionale ed internazionale

\section{SINTESI}

L'articolo è dedicato all' analisi del Regolamento generale sulla protezione dei dati, entrato in vigore il 25 maggio 2018, sul territorio degli Stati membri dell'Unione europea, confrontato con la normativa sui dati personali vigente in Ucraina. Vengono presi in considerazionei seguenti concetti base come "dati personali", "basi di dati personali", "protezione delle informazioni", "diritto di accesso all'informazione", "diritto di effettuare la cancellazione". Speciale attenzione è rivolta alle attività degli archivi nella raccolta, elaborazione, archiviazione ed accesso ai documenti che contengono informazioni personali. È analizzata la legislazione ucraina "sulle informazioni", "sulla protezione dei dati personali", "sull' accesso ad informazioni pubbliche", "sul Fondo archivistico nazionale e le istituzioni archivistiche". Viene sottolineato come il Regolamento abbia un valore molto importante per la vita socio-politica ed economica europea, per l'elaborazione di norme di protezione dei dati e di un nuovo quadro di protezione internazionale sulla privacy.

Parole chiave: protezione dei dati personali, Regolamento generale sulla protezione dei dati, Ucraina, legislazione archivistica, accesso alle informazioni

Varstvo osebnih podatkov in dostop do arhivov v Ukrajini z nacionalne in internacionalne perspektive

\section{IZVLE ČEK}

Prispevek je namenjen analizi splošne uredbe o varstvu podatkov, ki je začela veljati 25. maja 2018 na ozemlju držav članic Evropske unije, v primerjavi z zakonodajo o osebnih podatkih, ki deluje v Ukrajini. Upoštevani so naslednji osnovni koncepti: «osebni podatki», «zbirke osebnih podatkov», «zaščita informacij», «pravica do dostopa do informacij» in «pravica do izbrisa». Posebna pozornost je posvečena dejavnostim arhivov pri zbiranju, obdelavi, shranjevanju in zagotavljanju dostopa do gradiva, ki vsebujejo osebne podatke. Analizirani so Zakoni Ukrajinie «o informacijah», «o varstvu osebnih podatkov», «o dostopu do informacij javnega značaja», «o državnih arhivskih skladih in arhivskih institucijah». Ugotovljeno je, da ima BDP zelo pomembno vrednost za evropsko družbeno-politično in gospodarsko življenje, za oblikovanje standardov varstva podatkov in nov mednarodni okvir za varstvo zasebnosti.

Ključne besede: varstvo osebnih podatkov, splošna uredba o varstvu podatkov, Ukrajina, arhivsko pravo, dostop do informacij 
Maryna PALIIENKO: Personal Data Protection and Access to Archives in Ukraine: From the National and International Perspective, 60-70

Захист персональних даних та доступ до архівів в Україні у національному та міжнародному контексті

\section{АНОТАЦІЯ}

Стаття присвячена аналізу Загального регламенту про захист даних, який вступив у дію 25 травня 2018 р. на території країн-членів Європейського Союзу, у порівнянні з законодавством про персональні дані, що Аіє в Україні. Розглянуто такі засадничі поняття, як «персональна Аані», «бази персональних Ааних», «захист інформації», «право на доступ до інформації», «право на стирання / забуття». Спеціальна увага приділяється діяльності архівів щодо збирання, опрацювання, зберігання та надання у використання документів, що містять персональну інформацію. Аналізуються Закони України «Про інформацію», «Про захист персональних даних», «Про доступ до публічної інформації», «Про Національний архівний фонд та архівні установи». Зазначається, що Загальний регламент про захист Ааних має Ауже важливе значення Аля європейського соціально-політичного та економічного життя, ААя розробки стандартів захисту Ааних та нової міжнародної системи захисту приватного життя. Україна має адаптувати нові положення європейського законодавства.

КАючові слова: захист персональних даних, Загальний регламент про захист даних, Україна, архівне законодавство, доступ до інформації.

\section{Introduction}

On May 25, 2018 the General data protection regulation (GDPR) came into force that created a new situation not only in the legal field and the document circulation system of the EU member states but to a large extent influenced the market of informational, economic, educational, etc. services. It replaced Directive 95/46 / EC of the European Parliament and the Council "On Protection of Individuals in the Processing of Personal Data and the Free Movement of Such Data" (1995). The difference between these rules is, first of all, that the Regulation is a compulsory document and it does not require the implementation of its norms in the national legislation of each country separately.

The Regulation is of a direct relevance not only to all EU member states but also for those who are in political, economic, etc. relations with them. One of its main ideas is that principles and rules for the protection of individuals in respect of the processing of their personal data must be carried out regardless of the citizenship or place of residence of the persons, while respecting their fundamental rights and freedoms, in particular their right to protection of personal data. Therefore, it is also relevant to Ukraine that defined its priority task as the European integration vector of political, economic and socio-cultural development. The European regulation actually extend to Ukrainians, taking into account that a large number of major companies cooperate with the EU, they have branches or serve citizens of the European Union.

This article will discuss the current situation which has developed in Ukraine with the protection of personal data in the context of the development of the information society as well as the readiness of the country to accept and implement the main provisions of the Regulation for the successful development of bilateral and multilateral relations with European partners. Particular emphasis will be placed on the meaning of the Regulation and national legislation on personal data protection for archiving documents, activities of archival institutions and record keeping services as well as on the problems of the use of personal information in scientific research, journalistic and creative activities.

\section{Personal data protection: new european legislation and the situation in Ukraine}

Rapid development of information technologies strongly influenced the economy, public consciousness and began the formation of new social relations in the information sphere.

Economic integration and the development of the EU market in the context of the active use of information technology have led to a significant increase in cross-border flows of personal data, in particular due to the possibilities of the Internet. New technologies and globalization have brought with them new problems for the protection of personal data whereas the scale of their collection and use has greatly increased. 
The objective need to protect the privacy, individual freedoms and human security in the conditions of globalization and the development of the information society is largely determined by the potential threat of total control over the life of a person through modern information technology, systems and networks. A natural person from circumstances beyond his/her control becomes a subject to systematic or continuous observation related to the ordering and accumulation of information. This requires additional resources and the search for new ideas to enhance the legal effectiveness of protecting privacy and personal data.

The problems of personal data protection in the European and Ukrainian legislation were reflected in the works of Ukrainian scholars in the field of jurisprudence and information law, in particular, V.H. Pylypchuk (2017), V.M.Bryzko (2017), O.M.Rohova (2011).Comparative aspects of European and Croatian legislation on the protection of personal data are recently explored by a docent of Faculty of Law of Zagreb University N. Gumzej (2013). However, there are no studies of the impact of the norms of European legislation on the protection of personal data on the activities of Ukrainian archival institutions in historiography.

It has been pointed out, that the main legal standard that established the principles of harmonization of national legislation in the field of protection of personal data is Council of Europe Convention for the Protection of Individuals with regard to Automatic Processing of Personal Data (CETS No. 108, 28.01.1981). Subsequently, the principles of the Convention were detailed in the European Parliament and Council Directive 95/46/EC of October 24, 1995 "On the Protection of Individuals with regard to the Processing of Personal Data and the Free Circulation of this Data" (1995). These acts are considered the first international legal standards defining the conditions of unification of national legislation in the area of privacy and personal data protection for European countries.

Ukraine was ratified this Convention on July 6, 2010. The basis of this document was the protection of the fundamental freedoms of everyone, in particular the right to respect for privacy, in connection with automated processing of personal data. At the same time, the signatory countries have demonstrated their commitment to freedom of information regardless of frontiers.

In general, it should be noted that nowadays Ukrainian legislation has significant developments in the field of personal data protection. It consists of the Constitution of Ukraine, the Laws of Ukraine "On Protection of Personal Data", "On Information", "On Protection of Information in Informational and Telecommunicational Systems", other laws and normative legal acts, international treaties of Ukraine.

The Law of Ukraine "On information" (n. 2657-XII, 02.10.1992; current version 01.01.2017) for the first time in Ukraine defined in the legislative level the notions of "document" "protection of information", "information on a natural person (personal data)". According to this Law, information on a natural person means information or collection of information about an individual who identified or can be specifically identified (Art.11). Confidential information about a person (personal data) includes: nationality; education; marital status; religion; state of health; address; date and place of birth. By this law it is not allowed to collect, store, use, and distribute the confidential information about a person without his/her consent. Meanwhile, every person has a right to be familiarized with information on him/her. Information about the person shall be protected by the law.

The Law of Ukraine "On Protection of Personal Data" (n. 2297-VI), which was adopted on June 1, 2010 and currently operates in the version of January 30, 2018, regulates legal relations related to the protection and processing of personal data. It is aimed at protecting fundamental human rights and freedoms, in particular the right to privacy in connection with the processing of personal data. The scope of the law extends to the processing of personal data, which is undertaken wholly or partly with the use of automated means, as well as processing of personal data stored in a file folder, or assigned to be included in it, with the use of non-automated means (On Protection of Personal Data, Art.1).

The Ukrainian legislation on personal data protection contains the basic rules that are being introduced in the EU; however, the definition of the term "personal data" in the relevant Law of Ukraine is more general and concise than the corresponding definition of the European Commission. According to this Law, "personal data means information or a set of information about an individual (a natural person) who is identified or may be identified". (On Protection of Personal Data, Art.2) 
Meanwhile, according to the GDPR, "personal data means any information relating to an identified or identifiable natural person, directly or indirectly, in particular by reference to an identifier such as a name, an identification number, location data, an online identifier or to one or more factors specific to the physical, physiological, genetic, mental, economic, cultural or social identity of that natural person" (GDPR, Art.4, paragraph 1) The regulation has indeed significantly expanded the notion of personal data compared to the earlier Directive 95/46 /EC.

'Processing' means any operation or set of operations which is performed on personal data or on sets of personal data, whether or not by automated means, such as collection, recording, organisation, structuring, storage, adaptation or alteration, retrieval, consultation, use, disclosure by transmission, dissemination or otherwise making available, alignment or combination, restriction, erasure or destruction (GDPR, Art.4, paragraph 2)

Also, Article 4 of the Regulation defines the concepts of "genetic data" and "biometric data". In particular, in accordance with the Regulation, "biometric data means personal data resulting from specific technical processing relating to the physical, physiological or behavioural characteristics of a natural person, which allow or confirm the unique identification of that natural person, such as facial images or dactyloscopic data". (GDPR, Art.4, paragraph 14). Thus, the Regulation has extended its effect to a person's image, as well as an online identifier, which can be IP addresses, user's email addresses, social networking pages.

Special attention in the regulation is given to the formulation of the right of the subject to erase information ('right to be forgotten') - "the data subject shall have the right to obtain from the controller the erasure of personal data concerning him or her without undue delay and the controller shall have the obligation to erase personal data without undue delay" (GDPR, Art.17); while specifying the grounds for applying this rule as well as the grounds for its limiting.

The main attention of the Ukrainian law is focused on the processing of personal data, the creation and order of registration of personal data bases. An important norm of the law is the consent of the subject to processing his/her personal data.

Processing of personal data that is confidential is not allowed without the consent of the person except for the cases of national security, economic welfare and human rights. (On Protection of Personal Data, Art.6)

At the same time personal data may be processed for historical, statistical or scientific purposes only on condition that adequate level of its protection is ensured. (On Protection of Personal Data, Art.6, paragraph 9)

The processing of personal data shall be prohibited if such data is about racial or ethnic origin, political views, religious or other convictions, membership in political parties and trade unions, criminal charges or convictions as well as data with regard to health or sexual life. (On Protection of Personal Data, Art.7, paragraph 1)

The personal data subject shall have the right to: 1) know about the location of personal data base which contains his/her personal data, its purpose and name, location and/or place of residence of the controller or processor of such personal data, or to issue a respective proxy to the authorized persons, except for cases established by the law; 2) receive the information concerning the conditions of access to personal data, in particular information about third persons who obtain his/her personal data; 3) access his/her personal data; 4) receive a response with regard to whether his/her personal data is stored in a respective base of personal data as well as to receive the content of his/her personal data which are stored in such personal data base, no longer than in 30 days from the moment the request has been received; 5) submit motivated requests to a personal data controller objecting against processing his/her personal data; 6) provide a motivated request with regard to change or destruction of his/her personal data by any controller and processor of such personal data, if such data is processed illegally or are inaccurate; 7) protect of his/her personal data from illegal processing and accidental loss, destruction, damage due to a deliberate concealing, failure to provide them or provision of such data with delay, as well as to protection from provision of information which is inaccurate or are disgraceful for the honour, dignity and business reputation of a natural person; 8) lodge complaints regarding the processing of his/her personal data to 
government agencies and officials responsible for personal data protection or directly to a court; 9) apply measures of legal protection in case of violation of legislation on protection of personal data; 10) when granting consent, make reservations to restrict the right to process his/her personal data as well as withdraw consent to personal data processing; 11) be informed of the procedure for automated processing of personal data.

Access to personal data of third parties shall be determined by the permission terms between the base of personal data subject and the controller of the base of personal data as for processing this data or according to the access mode established by the law. (On Protection of Personal Data, Art.16)

If the personal data is in the possession of the public information manager, then the procedure for access to them is determined by the Law of Ukraine "On Access to Public Information" (n. 2939-VI, January 13, 2011). According to Article 10 of this Law, each person has the right to: 1) know, during collection of information but prior to its use, what information about him/her and for what purpose is being collected, in what way, by whom and with what purpose it is used, transferred or disseminated, except for instances, established by the law; 2) have access to information about him/her that is being collected and stored; 3) demand correction of inaccurate, incomplete, outdated information about him/her, destruction of information about him/her, whose collection, use or storing are carried out in violation of requirements of the law; 4) get compensation in case of disclosure of information about this person with violation of requirements established by the law.

The scope of information about a person that is collected, stored and used by information administrators must be maximally limited and used exclusively with the purpose and in a way specified by the law.

Information administrators, who possess information about a person, are obliged to: 1) provide it with no impediments and free of charge upon demand of the persons, whom it concerns, except for instances specified by the law; 2) use it only with the purpose and in a way specified by the law; 3) take measures to prevent unauthorised access to it by other persons; 4) correct inaccurate and outdated information about a person on their own or upon demand of persons, whom this information concerns.

In 2015, Article 10(1) of the Law on Access to Public Information - "Public Information in the Form of Open Data" - is additionally introduced. According to it, "public information in the form of open data means public information in a format that allows its automated processing by electronic means, free and free-of-charge access to it, as well as its reuse". Information administrators is obliged to provide public information in the form of open data upon request, publish and regularly update it on the unified state web-portal of open data and on their web-sites.

Public information in the form of open data shall be allowed for free reuse and dissemination. Any person may freely copy, publish, disseminate, use, including for commercial purposes, public information in the form of open data, in combination with other information or by including in their own product, with the mandatory reference to the source from which such information was received (On Access to Public Information, Art. 10(1), paragraph 2).

At the same time, public information that contains personal data of an individual shall be published and made available on request in the form of open data in that case, if at least one of the following conditions is satisfied: personal data are impersonal and protected in accordance with the Law of Ukraine "On Protection of Personal Data"; individuals (data subjects) have provided their consent for dissemination of such data in accordance with this Law, or restriction of access to such information is prohibited by the law.

In 2011 a specially created central executive body - the State Service of Ukraine for Personal Data Protection - started registering personal data databases in the State Register of personal data bases. However, due to the liquidation of this body in 2014, realization of its functions was entrusted to Ukrainian Parliament Commissioner for Human Rights. 


\section{Processing and use of personal data for scientific and creative purposes}

comparing the provisions of the Regulation and the Ukrainian law, it should be noted that the Regulation more precisely and in a balanced manner determines the possibilities of using personal data for scientific and creative purposes.

According to the Article 85 of the GDPR ("Processing and freedom of expression and information"), member states shall by law "reconcile the right to the protection of personal data with the right to freedom of expression and information, including processing for journalistic purposes and the purposes of academic, artistic or literary expression" (GDPR, Art. 85).

Moreover, according to the Article 86 ("Processing and public access to official documents"), member states shall also "reconcile public access to official documents with the right to the protection of personal data pursuant to this Regulation". In accordance with Article 89 (1), the possibilities of using personal data "for archiving purposes in the public interest, scientific or historical research purposes or statistical purposes" are determined.

In this regard, the Regulation develops the provisions of the Charter of Fundamental Rights of the European Union (2000/C 364/01), adopted on December 18 ${ }^{\text {th }}$, 2000, that considers to be fundamental rights, on the one hand, the protection of personal data (Art. 8) and, on the other hand, freedom of expression and information as well as freedom of the arts and sciences, including freedom of research (Charter of Fundamental Rights of the European Union, Art. 13).

Meanwhile, according to the relevant Ukrainian law, processing of the personal data in a form that allows the identification of an individual continues not longer than necessary for the legitimate purposes. Further processing of personal data "for historical, statistical or scientific purposes may be provided if they are adequately protected". (On Protection of Personal Data, Art.6, paragraph 8)

According to Article 25 of this law, processing of personal data without the provisions of this Law is allowed, if such processing is carried out: 1) by a natural person only for personal or household needs; 2) exclusively for journalistic and creative purposes, while ensuring there is a balance between the right to respect for private life and the right to freedom of expression.

Thereby, the Ukrainian law is not specifically emphasized the possibilities of using personal data for archiving purposes in the public interest, scientific or historical research purposes or statistical purposes.

\section{Access to documents of the national archival fond of ukraine that contain personal data}

according to both EU policy and the local policies of each individual state, archives are a basic and indispensable element of the cultural heritage. Since access to documents means the possibility to find out about the information included in the documents, access to public archives is itself a civil right, and hence a human right as well. This right is slowly becoming global, as users expect open access to archival materials via the Internet.

From the other hand, the archives, as government agencies, need to respect regulation on personal data protection, copyright, protection of intellectual property and other rights related to the privacy.

Modern policy in the field of archives requires a balance between openness and privacy (personal integrity). Nowadays it is especially important to Ukrainian state archives outlined legal framework for providing access to archival documents without causing any conflict of interest between the state and its citizens. In this respect, the development of archival affairs and archival legislation in Ukraine during the last two decades gives reasons to assert that the relations between archives and users are more and more consistent with general European legislation and approaches.

The Universal Declaration on Archives, adopted by the $36^{\text {th }}$ Session of the General Conference of UNESCO on $10^{\text {th }}$ November 2011, states that archives "plays an essential role in the development of societies by safeguarding and contributing to individual and community memory. Open access to archives enriches our knowledge of human society, promotes democracy, protects citizens' rights and enhances the quality of life". 
The process of democratization of the Ukrainian archival system and legislation can be traced on the example of liberalization of access to documents. The general principles for providing access to archival materials in Ukraine were outlined in the provisions of the Law of Ukraine "On the National Archival Fond and Archival Institutions" (No. 2888-14, adopted on December 13, 2001). In this edition it was taken into account the Council of Europe Recommendation No. R (2000)13 of the Committee of Ministers to Member States on a European policy on access to archives.

According to the Law of Ukraine "On the National Archival Fond and Archival Institutions", citizens of Ukraine have the right to use documents of the National Archival Fond or their copies on the basis of personal application and identification document. Foreigners and persons without citizenship, legally staying in Ukraine, have the same rights of access to documents of the National Archival Fond, as well as they have the same obligations as citizens of Ukraine (Art.15). Simultaneously the law prohibits require any other documents from the user.

Access to documents of the National Archival Fond, which contain confidential information on a person, is restricted for 75 years from the moment of their creation, if the other is not provided by the law (Art.16). Before this term, access is possible at consent of a person, whose rights and legal interests might be violated.

In the same time, due to the adoption on April 9, 2015 the Law of Ukraine "On Access to Archives of Repressive Bodies of the Communist Totalitarian Regime of 1917-1991" (n. 316-VIII), several amendments were made to the laws "On the National Archival Fond and Archival Institutions" and "On Protection of Personal Data". Taking into account the Recommendations of the Committee of Ministers of the Council of Europe to the Member States regarding the European policy of access to archives No. R (2000) 13, the Verkhovna Rada of Ukraine recognized the need for broad access to historical information, emphasizing that the right of everyone to receive objective information about the history of their country is one of the foundations of a democratic state. The main reasons for the adoption of this Law were the desire to establish a social dialogue and prevent a recurrence of crimes of totalitarian regimes; any discrimination based on national, social, class, ethnic, racial or other characteristics in the future; resumption of historical and social justice, prevention of threat to independence, sovereignty, territorial integrity and national security of Ukraine.

In accordance with this Law, archival information on repressive organs on staff or off-staff employees of repressive bodies is open; access to such information cannot be restricted for any reason (On Access to Archives of Repressive Bodies, Art.8). The victim of repressive organs, by imposing restrictions on access to information about him/her, should clearly indicate what information and for what period the restrictions are set (type of information, pages, paragraphs, etc.) (On Access to Archives of Repressive Bodies, Art.9). Family members and relatives of those who are victims of repressive organs have the right to partly restrict access to information about them. In this case, the person has the right to restrict access only to his racial (ethnic) origin, political or philosophical views, religion, as well as data relating to health and sexual life (On Access to Archives of Repressive Bodies, Art.9, paragraph 3).

At the same time the mentioned persons have the right to restrict access to archival information of the repressive bodies about themselves for a term of no more than 25 years. If the archival information of the repressive bodies on individuals has been already published, the restriction of access to such information shall not apply.

Provision of access to archival documents in archival institutions is carried out on the basis of a document certifying a person, as well as a completed application form. It is prohibited to require the person to provide any other documents.

A researcher has the right to free access to archival information data in the reading room of the archival institution or copies thereof, taking into account the restrictions established by this Law. A person may make copies of archival documents of the repressive bodies, including by its own technical means, or receive copies of documents from archival institutions and extracts from them, if this does not threaten the state of documents.

Before starting work with archival resources, the person is informed that he/she is fully responsible for the form and content of the widespread of archival information, as well as for all possible legal consequences of such dissemination. 
To my mind, nowadays it is very important to keep balance between access to earlier restricted information, its usages and dissemination. First of all, it concerns the information about victims as well as public figures of soviet totalitarian regime. The usage of personal data and the dissemination of information on the activities of these persons should be based on a scientific analysis and comparison of facts derived from various sources. We must prevent the dissemination of inappropriate and inaccurate information. The former head of the State Committee on Archives of Ukraine G. Boryak already focused his attention on this issue in the early 2000s. In particular, he noted that among the archival documents of the former Communist Party of Ukraine there are many personal data, biographical papers, complaints, accusations, etc. Not all of them have objective information, but they can be used in a modern political struggle. (Боряк,2004, 7).

\section{Conclusion}

It has been pointed out that the General data protection regulation has very important value for European socio-political and economic life, working out data protection standards and a new international privacy protection framework. Ukraine has to adapt the new positions of this legislation. A new approach has been applied in the Regulations regarding the term "archiving in the public interest", that could be implemented in the Ukrainian legislative and archival practice.

Archives services should work in close partnership with the data protection officers; they should safeguard the integrity and authenticity of documents containing personal data as well as misrepresenting facts or information in the documents. In order to meet the requirements of the Regulation archives services should implement data protection guidelines for their archival information management systems.

At the same time, the problem of unlawful and unauthorized actions in the area of personal data of individuals remains relevant and clearly unresolved, both in legal and in practical terms.

Nowadays in Ukraine, we still have a problem with the practical implementation of the provisions of the law on personal data protection. Although information is protected by law, there is an illegal trade in CDs with personal data.

All this puts new tasks in front of the Ukrainian legislative system as well as research and archival practice. The State Archival Service of Ukraine service and archival institutions need to implement adequate security measures and mechanisms in order to protect the confidential information and at the same time provide access to documents especially for historical research and socio-cultural purposes for the sake of freedom and democracy.

\section{References}

General Data Protection Regulation (GDPR) in a current version of the OJ L 119, 04.05.2016. Available at https://gdpr-info.eu/ (accessed on 15.06.2018).

Convention for the Protection of Individuals with regard to Automated Processing of Personal Data (CETS No. 108, 28.01.1981). Available at https://www.coe.int/en/web/conventions/full-list/-/conventions/treaty/108 (accessed on 16.06.2018).

Directive No. 95/46/EC of the European Parliament and of the Council of 24 October 1995 on the protection of individuals with regard to the processing of personal data and on the free movement of such data. In: Official Journal of the European Communities, L 281, 23.11.1995, pp.31-50. Available at http://www.wipo.int/wipolex/en/ details.jsp?id=13580 (accessed on 15.06.2018).

The Charter of Fundamental Rights of the European Union (2000/C 364/01). In: Official Journal of the European Communities, C 364, 18 December 2000. Available at https://eur-lex.europa.eu/legal-content/en/ $\mathrm{ALL} /$ ?uri=OJ\%3AC\%3A2000\%3A364\%3ATOC (accessed on 18.06.2018).

The Council of Europe Recommendation No. R (2000) 13 of the Committee of Ministers to Member States on a European policy on access to archives. Available at http://www.archives.gov.ua/Eng/Law-base/Recommendations. php\#01 (accessed on 15.06.2018). 
The Universal Declaration on Archives, adopted by the 36th Session of the General Conference of UNESCO on 10th November 2011. Available at https://www.ica.org/en/universal-declaration-archives (accessed on 18.06.2018).

Archival Legislation of Ukraine: Law of Ukraine on the National Archival Fond and Archival Institutions (2001); Regulations for the Use of Documents of the National Archival Fond of Ukraine (2003). Kyiv, 2003, 38 p. Available at http://www.archives.gov.ua/Eng/Access/access.php (accessed on 25.05.2018).

Закон України "Про захист персональних даних" (n. 2297-VI) віА 01.06.2011 у редакції віА 30.01.2018. Available at http://zakon0.rada.gov.ua/laws/show/2297-17 (accessed on 25.06.2018).

Закон України “Про інформацію” (n. 2657-XII) від 02.10.1992 у поточній редакції від 01.01.2017. Available at http://zakon3.rada.gov.ua/laws/show/2657-12 (accessed on 26.05.2018).

Закон України “Про доступ до публічної інформації” (n. 2939-VI) від 13.01.2011 у редакції від 01.05.2015. Available at http://zakon3.rada.gov.ua/laws/show/2939-17 (accessed on 25.05.2018).

Закон України “Про внесення змін до деяких законів України щодо доступу до публічної інформації у формі відкритих Ааних" (Відомості Верховної Ради (ВВР), 2015, n. 25, ст.192). Available at http://zakon3.rada. gov.ua/laws/show/319-19/paran27\#n27 (accessed on 17.06.2018).

Закон України “Про Національний архівний фонд та архівні установи” (n. 3814-12) віА 24.12.1993 у редакції віА 13.12.2001 (n. 2888-14). Available at http://zakon3.rada.gov.ua/laws/show/2888-14 (accessed on 25.05.2018).

Закон України "Про доступ до архівів репресивних органів комуністичного тоталітарного режиму 19171991 років" (2015). Available at http://zakon5.rada.gov.ua/laws/show/316-19 (accessed on 25.05.2018).

Law of Ukraine "On Protection of Personal Data". Available at http://cedem.org.ua/en/library/law-of-ukraineon-protection-of-personal-data/ (accessed on 15.06.2018).

Law of Ukraine "On Access to Public Information" (2011). Available at http://cedem.org.ua/en/library/ law-on-access-to-public-information (accessed on 17.06.2018).

Боряк, Геннадій, Новохатський, Костянтин (2004). Модерне архівне законодавство України. In: Архіви України, 3 (254), pp. 4-10.

Пимипчук, В.Г., Брижко, В.М. (2017) Трансформація системи захисту персональних Ааних та приватності в контексті євроінтеграції України. In: Вісник Національної академії правових наук України, 3 (90), pp. 36-50.

Пимипчук, В.Г., Брижко, В.М. (2017) Реформування і розвиток системи захисту персональних даних в Україні. In: Інформащіл і право, 3, pp. 5-21.

Рогова, О.Г. (2011) Захист персональних даних у законодавстві Європейського Союзу та України. In: Teорія та практика державного управління, 3, pp. 464-471.

Gumzej, Nina (2013) Selected Aspects of Proposed New EU General Data Protection Legal Framework and the Croatian Perspective. In: Juridical Tribune, 2, pp. 178-201.

Gumzej, Nina (2013) The Council of Europe and the Right to Personal Data Protection: Embracing Postmodernity. In: Conference of the International Journal of Arts and Sciences, pp. 13-33.

\section{SUMMARY}

On May 25, 2018 the General data protection regulation (GDPR) came into force that created a new situation not only in the legal field and the document circulation system of the EU member states but to a large extent influenced the market of informational, economic, educational, etc. services. One of its main ideas is that principles and rules for the protection of individuals in respect of the processing of their personal data must be carried out regardless of the citizenship or place of residence of the persons, while respecting their fundamental rights and freedoms, in particular their right to protection of personal data. This article is discussed the current situation which has developed in Ukraine with the protection of personal data in the context of the development of the information society as well as the readiness of the country to accept and implement the main provisions of the Regulation for the successful development of bilateral and multilateral relations with European partners. Particular emphasis are placed on the meaning of the Regulation and national legislation on personal data protection for archiving documents, activities of archival institutions and record keeping services as well as on the problems of the use of personal information in scientific research, journalistic and creative activities. The Ukrainian legislation on 
Maryna PALIIENKO: Personal Data Protection and Access to Archives in Ukraine: From the National and International Perspective, 60-70

personal data protection contains the basic rules that are being introduced in the EU; however, the definition of the term "personal data" in the relevant Law of Ukraine is more general and concise than the corresponding definition of the European Commission. Comparing the provisions of the Regulation and the Ukrainian law, it should be noted that the Regulation more precisely and in a balanced manner determines the possibilities of using personal data for scientific and creative purposes. A new approach has been applied in the Regulations regarding the term "archiving in the public interest", that could be implemented in the Ukrainian legislative and archival practice.

Typology: 1.01 Original scientific article

Submission date: 23.07.2018

Acceptance date: 08.08.2018 